\title{
PENGARUH KEMAMPUAN KERJA DAN PROFESIONALISME PEGAWAI TERHADAP KINERJA PEGAWAI PADA DINAS PARIWISATA KABUPATEN BALANGAN PROVINSI KALIMANTAN SELATAN
}

\author{
Yudhi Arisa Putra \\ Sekolah Tinggi Ilmu Ekonomi Pancasetia Banjarmasin \\ Jl. Ahmad Yani Km. 5.5 Banjarmasin \\ arisayudhie@gmail.com
}

\begin{abstract}
Abstrak: Yudhi Arisa Putra, Npm. 1911.32202.5174, Pengaruh Kemampuan Kerja Dan Profesionalisme Pegawai Terhadap Kinerja Pegawai pada Dinas Pariwisata Kabupaten Balangan Provinsi Kalimantan Selatan Dibawah Bimbingan Dr. Lanny Purnama Kosasi,MM Dan Drs.M.Zaid Abdurakhman, MM, 2021. Tujuan penelitian untuk mengetahui pengaruh kemampuan kerja dan profesionalisme pegawai secara simultan terhadap kinerja pegawai, untuk mengetahui pengaruh kemampuan kerja dan profesionalisme pegawai secara parsial terhadap kinerja pegawai dan untuk mengetahui diantara kemampuan kerja dan profesionalisme pegawai yang berpengaruh dominan terhadap kinerja pegawai Dinas Pariwisata Kabupaten Balangan Propinsi Kalimantan Selatan. Populasi dan sampel dalam penelitian ini ditentukan sebanyak 40 respoden. Teknik pengolahan data yang akan dilakukan menggunakan metode kuantitatif dengan analisis regresi berganda.Hasil penelitiakemampuan kerja dan profesionalisme pegawai berpengaruh signifikan secara simultan terhadap kinerja pegawai, kemampuan kerja dan profesionalisme pegawai berpengaruh signifikan secara parsial terhadap kinerja pegawai dan profesionalisme pegawai berpengaruh dominan terhadap kinerja pegawai pada Dinas Pariwisata Kabupaten Balangan Propinsi Kalimantan Selatan.
\end{abstract}

Kata Kunci : Kemampuan Kerja, Profesionalisme, dan Kinerja.

Abstract

Abstract: Yudhi Arisa Putra, Npm. 1911.32202.5174, Effect Of Employee Ability And Employee Professionalism On The Performance Of Tourism Service Employees In Balangan Regency Province South Kalimantan, Under Guidance Dr.Lanny Purnama Kosasi,MM and Drs.M.Zaid Abdurakhman,MM, 2021. The purpose of the study was to determine the effect of work ability and professionalism of employees simultaneously on employee performance, to determine the effect of work ability and professionalism of employees partially on employee performance and to find out between work ability and employee professionalism which had a dominant influence on employee performance at the Tourism Office of Balangan Regency, Kalimantan Province. South. The population and sample in this study were determined as many as 40 respondents. The data processing technique will be carried out using quantitative methods with multiple regression analysis. The results of the research that work ability and employee professionalism have a significant simultaneous effect on employee performance, work ability and employee professionalism have a partially significant effect on employee performance and employee professionalism has a dominant influence on employee performance at the Tourism Office of Balangan Regency, South Kalimantan Province.

Keywords: Work Ability, Professionalism, and Performance 


\section{BAB I PENDAHULUAN \\ 1.1. Latar Belakang Masalah}

Berbicara profesionalisme aparatur negara merupakan hal yang sangat penting, karena dengan adanya profesionalisme pegawai, maka tugas dan fungsi organisasi dapat tercapai sesuai tujuan dengan misi secara optimal menurut standar tertentu yang telah diharapkan oleh organisasi itu sendiri maupun untuk berkepentingan masyarakat melalui pelayanan yang baik dan prima. Profesionalisme pegawai sebagai sikap dan prilaku pegawai yang mampu dan handal serta berpengetahuan luas dalam bidangnya diharapkan mampu melakukan pekerjaannya dalam melayani masyarakat banyak sesuai dengan bidang yang digelutinya. Pegawai yang profesional yang dimaksud tentunya dipengaruhi oleh proses rekrutmen awal atau penerimaan sejak calon pegawai diuji kemampuan dan sikapnya untuk menjadi pegawai, insentif, pendidikan dan pelatihan serta sistem pembinaan karier yang terencana dengan baik. Selain itu guna menciptakan profesionalisme aparatur negara namun hal tersebut harus pula didukung oleh pembangunan sumber daya manusia melalui peningkatan kemampuan pegawai. Untuk mendapatkan pegawai yang berkualitas tinggi dengan cara meningkatkan sumber daya manusia di institusi pemerintah. Yang dapat dilihat dari kemampuannya, sehingga dapat menghasilkan suatu pegawai yang efektif. Sumber daya manusia adalah asset yang sangat berharga dan merupakan salah satu faktor penting dalam menunjang keberhasilan pelaksanaan kegiatan suatu organisasi. Oleh sebab itulah, maka sumber daya manusia perlu memiliki kemampuan untuk berkembang secara rasional dan juga mempunyai kemampuan untuk berkembang secara terus menerus dan berkesinambungan, karena pegawai memberikan konstribusi yang sangat besar bagi organisasi dalam proses pencapaian tujuan yang telah ditetapkan. Untuk mempersiapkan kerja para pegawai agar dapat memiliki kemampuan kerja yang baik. Salah satu langkah yang diambil dalam komitmen pemerintah daerah mengembangkan sektor pariwisata di Balangan yaitu, dengan membentuk Dinas Pariwisata secara khusus, dari yang mulanya hanya berupa bidang di Dinas Pemuda Olahraga Pariwisata dan Kebudayaan (Disporaparbud). Pemerintah Daerah Kabupaten Balangan mengakui bahwa, sektor pariwisata memang menjadi perhatiannya dan masuk program jangka panjang untuk persiapan Balangan ke depannya terlebih pasca tambang. Selain pertanian, pariwisata menjadi salah satu andalan kami di masa mendatang untuk mendongkrak PAD dan ekonomi masyarakat, menggantikan posisi tambang. Namun untuk saat ini memang belum bisa memberikan anggaran berlebih untuk pembenahan pariwisata, karena masih banyak sektor lain yang menjadi prioritas utama, seperti infrastruktur dan pertanian serta peningkatan kualitas SDM.Keberadaan SDM berperanan penting dalam pengembangan pariwisata. SDM pariwisata mencakup wisatawan/pelaku wisata (tourist) atau sebagai pekerja (employment). Peran SDM sebagai pekerja dapat berupa SDM di lembaga pemerintah, SDM yang bertindak sebagai pengusaha (wirausaha) yang berperan dalam menentukan kepuasan dan kualitas para pekerja, para pakar dan profesional yang turut berperan dalam mengamati, mengendalikan dan meningkatkan kualitas kepariwisataan serta yang tidak kalah pentingnya masyarakat di sekitar kawasan wisata yang bukan termasuk ke dalam kategori di atas, namun turut menentukan kenyamanan, kepuasan para wisatawan yang berkunjung ke kawasan tersebut. Pariwisata sebagai sebuah industri yang sangat bergantung pada keberadaan manusia. Terwujudnya pariwisata merupakan interaksi dari manusia yang melakukan wisata yang berperan sebagai konsumen yaitu pihak-pihak yang melakukan perjalanan wisata/wisatawan dan manusia sebagai produsen yaitu pihak-pihak yang menawarkan produk dan jasa wisata. Sehingga aspek manusia salah satunya berperan sebagai motor penggerak bagi kelangsungan industri pariwisata di suatu negara. Dinas Pariwisata Kabupaten Balangan Propinsi Kalimantan Selatan merupakan sebuah lembaga pemerintah daerah yang bergerak dalam bidang pengelolaan pariwisata didaerah dengan tugas menyusun rencana kerja Dinas Pariwisata, pelayanan pembinaan dan pengendalian urusan pemerintahan bidang pariwisata. Observasi awal peneliti terhadap aktivitas kerja pegawai di Dinas Pariwisata Kabupaten Balangan Propinsi Kalimantan Selatan yang dinilai dari aspek kemampuan kerja selama ini terdapat fenomena masih ada pegawai yang memiliki kemampuan kerja yang kurang maksimal hal ini terlihat saat pegawai diserahi tanggung jawab sering kali kurang mampu menjalankan tugas tersebut dan masih ada sebagian pegawai kurnag mempunyai kemampuan dalam hal teknologi, akibat 
keterbatasan kemampuan tersebut berdampak terhadap kinerja pegawai menjadi kurnag maksimal.Fenomena selanjutnya terkait aspek profesionalisme pegawai, selama ini terkesan sebagian pegawai Dinas Pariwisata Kabupaten Balangan Propinsi Kalimantan Selatan kurang profesional dalambekerja hal telihat masih adanya pegawai yang bekerja tidak sesuai dengan aturan kerja serta masih terlihat pegawai kurang efektifnya penegakan peraturan-peraturan bekerja seperti pegawai dalam bekerja masih terlihat sering terlambat dalam bekerja, membuangbuang waktu dan adanya budaya suka menundanunda.Akibat belum optimalnya kemampuan kerja dan profesionalisme pegawai tersebut, sehingga kerap kali mempengaruhi aktivitas dan kinerja pegawai menjadi kurang optimal seperti belum tercapainya program kerja yang diharapkan, maupun aktivitas pengembangan pariwisata yang dirasakan belum mencapai sesuai dengan yang diharapkan.

\subsection{Rumusan Masalah}

Berdasarkan latar belakang yang telah penulis kemukakan tersebut, yang menjadi perumusan masalah dalam penelitian ini adalah :

1. Apakah kemampuan kerja dan profesionalisme pegawai berpengaruh signifikan secara simultan terhadap kinerja pegawai pada Dinas Pariwisata Kabupaten Balangan Propinsi Kalimantan Selatan?

2. Apakah kemampuan kerja dan profesionalisme pegawai berpengaruh signifikan secara parsial terhadap kinerja pegawai pada Dinas Pariwisata Kabupaten Balangan Propinsi Kalimantan Selatan?

3. Manakah diantara kemampuan kerja dan profesionalisme pegawai yang berpengaruh dominan terhadap kinerja pegawai pada Dinas Pariwisata Kabupaten Balangan Propinsi Kalimantan Selatan?

\section{BAB II}

\subsection{Landasan Teori}

\section{TINJAUAN PUSTAKA}

\subsubsection{Kemampuan Kerja}

Swasto (2011:130) kemampuan menunjukkan potensi orang untuk melaksanakan tugas dan pekerjaan. Rivai (2012:217) menjelaskan kemampuan berhubungan erat dengan kemampuan fisik dan mental yang dimiliki orang dalam melaksanakan pekerjaan. Kemampuan karyawan rendah akan menggunakan waktu dan usaha lebih besar dari pada karyawan yang berkemampuan tinggi untuk menyelesaikan suatu pekerjaan. Setiap jenis pekerjaan menurut pengetahuan, keterampilan dan sikap tertentu agar dapat melaksanakan pekerjaan dengan baik.Menurut Amstrong dan Baron, (2010:297) menjelaskan competence dan competency. Competence menggambarkan apa yang dibutuhkan seseorang agar ia mampu melaksanakan pekerjaannya dengan baik. Pengertian competence ini memberikan perhatian pada akibat (effect) dari pada usaha (effort) dan pada output dari pada input. Competency mengacu pada dimensi perilaku, sehingga sering disebut kompetensi perilaku bagaimana orang berperilaku ketika mereka melakukan perannya dengan baik. Robbins, (2011:210) menerangkan kompetensi/ kemampuan sebagai karakteristik yang mendasar yang dimiliki seseorang yang berpengaruh langsung terhadap atau dapat memprediksikan, kinerja yang sangat baik. Kompetensi adalah apa yang para outstanding performers lakukan lebih sering pada lebih banyak situasi dengan hasil yang lebih baik dari pada yang dilakukan avarage performers. Winardi (2011:88) kemampuan kerja secara umum diartikan sebagai kecakapan, keterampilan, kemampuan. Kata dasarnya sendiri yaitu kompeten, tentu saja berarti cakap, mampu, atau terampil. Pada konteks manajemen SDM istilah kompetensi mengacu kepada atribut/karakteristik seseorang yang membuatnya berhasil dalam pekerjaannya.

Robbins (2011:140) untuk mengetahui seorang karyawan mampu atau tidak dalam melaksanakan pekerjaan dapat dilihat melalui beberapa indikator kemampuan kerja berikut ini:

1. Kesanggupan kerja, suatu kondisi dimana seorang karyawan mampu menyelesaikan pekerjaan yang diberikan kepadanya.

2. Pendidikan adalah kegiatan untuk meningkatkan pengetahuan seseorang termasuk didalamnya peningkatan penguasan teori dan keterampilan melalui pendidikan formal dan non formal.

3. Masa kerja adalah waktu yang dibutuhkan seseorang dalam bekerja pada sebuah organisasi.

Winardi (2011:87) menjelaskan indikator dari kemampuan kerja adalah:

1. Keterampilan adalah keterampilan dan kecakapan pegawai sebagai akumulasi dari bakat dan keperibadian yang dimiliki. Indikatornya meliputi: mampu menyelesaikan tugas tepat waktu, kreatif, inovatif dan 
memiliki kemampuan untuk menghitung cepat dan mengoperasikan komputer.

2. Pengetahuan adalah pengetahuan yang dimiliki sebagai hasil pendidikan, pengalaman dan pelatihan dibidang pekerjaannya. Indikatornya latar belakang pendidikan sesuai bidang pekerjaan dan sering mengikuti pelatihan dibidangnya.

3. Pengalaman kerja adalah pengalaman kerja yang dimiliki pegawai. Indikatornya menguasai pekerjaan dengan baik, masa kerja yang cukup panjang dan kepindahan tempat kerja yang tinggi.

\subsubsection{Profesionalisme Pegawai}

Suseno (2011:97) profesional adalah pekerja yang menjalankan profesi. Setiap profesional berpegang pada nilai moral yang mengarahkan dan mendasari perbuatan luhur. Dalam melakukan tugas profesi, para profesional harus bertindak objektif, artinya bebas dari rasa malu, sentimen, benci, sikap malas dan enggan bertindak. Dengan demikian seorang profesional jelas harus memiliki profesi tertentu yang diperoleh melalui sebuah proses pendidikan maupun pelatihan yang khusus, dan disamping itu pula ada unsur semangat pengabdian (panggilan profesi) didalam melaksanakan suatu kegiatan kerja. Hal ini perlu ditekankan benar untuk membedakannya dengan kerja biasa (occupation) yang semata bertujuan untuk mencari nafkah dan/ atau kekayaan materiil duniawi. Menurut Korten dan Alfonso, dalam (Tjokrowinoto, 2016: 178), bahwa profesionalisme adalah kecocokan (fitness) antara kemampuan yang dimiliki oleh birokrasi (bureaucratic-competence) dengan kebutuhan tugas (task-requirement). Pegawai yang memiliki kemampuan yang sejalan dengan kebutuhan tugas yang dilakukannya dalam bekerja merupakan syarat terciptanya pegawai yang profesional. Maksudnya kemampuan dan keahlian pegawai merupakan suatu pencerminan dari arah dan tujuan yang ingin dicapai sebuah organisasi. Dengan demikian, apabila bagian organisasi ingin melayani masyarakat banyak untuk terciptanya good governance, maka Bagian Organisasi haruslah memiliki aparat yang profesionalisme demi tercapainya tujuan organisasi. Selanjutnya pendapat Siagian (2011:163), mengatakan, bahwa profesionalisme merupakan keandalan dalam pelaksanaan tugas sehingga terlaksana dengan mutu tinggi, waktu yang tepat, cermat dan dengan prosedur yang mudah dipahami dan diikuti oleh pelanggan. Pegawai yang profesional akan handal dalam bertugas yang pada akhirnya akan menghasilkan kerja yang bermutu tinggi, waktu yang tepat prosedur yang bisa diikuti masyarakat yang dilayaninya. Supaya handal tentunya dibutuhkan pendidikan dan latihan yang akan mendukung pegawai dalam bekerja agar dapat merespon kebutuhan dan perkembangan lingkungan yang semakin pesat pada era otonomi sekarang agar bisa melayani kepentingan masyarakat secara efektif dan memiliki daya inovatif yang tinggi mengacu pada visi dan misi Organisasi. Sejalan dengan yang telah dikemukakan oleh Ancok (2011:75), bahwa profesionalisme adalah kemampuan beradaptasi terhadap lingkungan yang cepat berubah dan menjalankan tugas dan fungsinya dengan mengacu pada visi dan nilainilai organisasi. Menurut Kartasasmita (2014:10), bahwa profesionalisme mencerminkan sikap seseorang terhadap profesinya, kesungguhan hati untuk mendalami, menerapkan, dan bertanggungjawab atas profesinya. Wignjosoebroto, profesionalisme adalah suatu paham yang mencitakan dilakukannya kegiatan-kegiatan kerja tertentu dalam masyarakat, berbekalkan keahlian yang tinggi dan berdasarkan rasa keterpanggilan serta ikrar (fateri/profiteri) untuk menerima panggilan tersebut untuk dengan semangat pengabdian selalu siap memberikan pertolongan kepada sesama yang tengah dirundung kesulitan ditengah gelapnya kehidupan.

Kemudian menurut Suradinata (2015:101) adapun sikap seorang yang professional, yaitu komitmen tinggi, tanggung jawab, berfikir sistematis, penguasaan materi dan menjadi bagian masyarakat profesional

Faktor yang mendukung sikap profesionalisme menurut Royen (2001) dalam Sanyoto, (2010:121) adalah :

a. Performance dapat diartikan sebagai prestasi kerja, pelaksanaan kerja, penampilan kerja. Performance atau kehandalan serta prestasi kerja adalah hasil yang diinginkan dari prelaku, prestasi yang dihasilkan dalam urutan maupun kurun waktu tertentu.

b. Akuntabilitas merupakan kebijakan startegis, hal ini harus dapat di implementasikan untuk menciptakan kepatuhan pelaksanaan tugas dan kinerja pegawai.

c. Loyalitas aparatur yang berkaitan dengan kesetiaan terkait satu sama lain dan tidak ada kesetiaan yang mutlak diberikan kepada satu jenis kesetiaan tertentu dengan mengabaikan yang lainnya. 
d. Kemampuan Aparatur / Pegawai merupakan salah satu unsur kematangan yang berkaitan dengan pengetahuan dan keterampilan yang diperoleh dari pendidikan dan pelatihan serta pengalaman.

\subsubsection{Kinerja Pegawai}

Istilah prestasi kerja berasal dari kata $J o b$ Performance atau Actual Performance (prestasi kerja atau prestasi sesungguhnya yang dicapai seseorang). prestasi didefinisikan secara formal sebagai sejumlah dan kualitas dari tugas yang terselesaikan secara individu, kelompok atau organisasi. Kinerja adalah hasil kerja secara kualitas dan kuantitas yang dicapai oleh seorang pegawai dalam melaksanakan tugasnya sesuai dengan tanggung jawab yang di berikan kepadanya. Selain itu, kinerja juga dapat diartikan sebagai suatu hasil dan usaha seseorang yang di capai dengan adanya kemampuan dan perbuatan dalam situasi tertentu. (Mangkunegara, 2015: 67) Menurut Soeprihantono, (2012:98) kinerja mempunyai makna lebih luas, bukan hanya menyatakan sebagai hasil kerja, tetapi juga bagaimana proses kerja berlangsung. Kinerja adalah tentang melakukan pekerjaan dan yang dihasilkan dari pekerjaan tersebut. Kinerja adalah adalah tentang apa yang dikerjakan dan bagaimana cara mengerjakannya. Kinerja merupakan hasil pekerjaan yang mempunyai hubungan kuat dengan tujuan strategis organisasi kepuasan konsumen (pengguna) dan memberikan kontribusi ekonomi. Sedangkan menurut Notoatmodjo dan Soekidjo, (2011:15) bahwa kinerja adalah hasil pekerjaan seorang karyawan selama periode tertentu dibandingkan dengan berbagai kemungkinan, misalnya standar, target / sasaran / kriteria yang telah ditentukan terlebih dahulu dan telah disepakati bersama. Basri (2009:80), kinerja bahan perbandingan antara totalitas pengeluaran pada waktu tertentu dibagi totalitas masukan selama periode tertentu. Kinerja juga sikap mental yang mempunyai semangat untuk bekerja keras dan ingin memiliki kebiasaan untuk melakukan peningkatan perbaikan. Menurut As'ad (2012: 67) "kinerja adalah hasil kerja secara kualitas dan kuantitas yang dicapai oleh seorang pegawai dalam melaksanakan tugasnya sesuai dengan tanggung jawab yang di berikan kepadanya.

Menurut Guritno dan Waridin (2011:78), yaitu mampu meningkatkan target pekerjaan, yaitu pegawai mampu menjalankan tugas sesuai dengan target yang ditetapkan, Pegawai mampu menyelesaikan pekerjaan tepat waktu sesuai dengan yang ditetapkan, pegawai mampu menciptakan inovasi menyelesaikan pekerjaan yang telah diamanahkan kepadanya, pegawai mampu menciptakan kreativitas menyelesaikan pekerjaan yang dikerjakannya dan pegawai mampu meminimalkan kesalahan pekerjaan dalam setiap pekerjaan yang dikerjakannya.

Menurut Gibson (2010:90) ada tiga faktor yang dapat mempengaruhi kinerja seseorang antara lainfaktor Individu : kemampuan, keterampilan, latar belakang keluarga, pengalaman tingkat sosial dan demografi seseorang. Faktor Psikologis : peersepsi, peran, sikap, kepribadian, motivasi dan kepuasan kerja. Faktor Organisasi : Struktur organisasi, desain pekerjaan, kepemimpinan, sistem penghargaan.

\section{BAB III \\ KERANGKA KONSEPTUAL DAN HIPOTESIS}

\subsection{Kerangka Konseptual}

Berdasarkan penjelasan tersebut berikut kerangka konseptual dalam penelitian ini dapat dilihat pada gambar 3.1 dibawah ini:

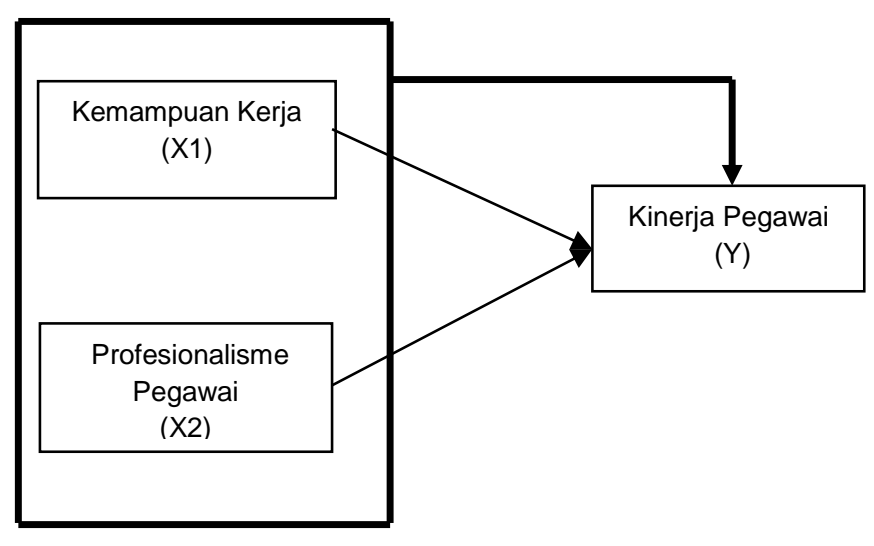

\subsection{Hipotesis Penelitian}

Berdasarkan permasalahan serta kerangka disebutkan diatas, maka hipotesis (dugaan sementara) yang diajukan dalam penelitian ini adalah:

1. Kemampuan kerja dan profesionalisme pegawai berpengaruh signifikan secara simultan terhadap kinerja pegawai pada Dinas Pariwisata Kabupaten Balangan Propinsi Kalimantan Selatan.

2. Kemampuan kerja dan profesionalisme pegawai berpengaruh signifikan secara parsial terhadap kinerja pegawai pada Dinas Pariwisata Kabupaten Balangan Propinsi Kalimantan Selatan. 
3. Profesionalisme pegawai berpengaruh dominan terhadap kinerja pegawai pada Dinas Pariwisata Kabupaten Balangan Propinsi Kalimantan Selatan.

\section{BAB IV}

\subsection{Rancangan Penelitian}

\section{METODE PENELITIAN}

Rancangan penelitian menjelaskan akan konsep dasar dalam penelitian ini, dimana rancangan penelitian ini merupakan suatu penelitian yang berbentuk infresial dengan menggunakan pendekatan positifistik, yaitu pendekatan yang menggunakan pola pikir edukatif dengan melihat gejala-gejala umum kemudian di lanjutkan kehalhal yang lebih khusus, di mana data yang dikumpulkan dari hasil kuisioner.

\subsection{Definisi Operasional Variabel}

Penguraian definisi operasional variabel yang diteliti

1. Kemampuan kerja (X1) merupakan kesanggupan seorang pegawai untuk melakukan pekerjaan yang menjadi tanggung jawabnya.

2. Profesionalisme pegawai (X2) mencerminkan sikap seseorang terhadap profesinya, kesungguhan hati untuk mendalami, menerapkan, dan bertanggungjawab atas profesinya.

3. Kinerja pegawai (Y) yaitu hasil pekerjaan seorang karyawan selama periode tertentu dibandingkan dengan berbagai kemungkinan, misalnya standar, target/sasaran/kriteria yang telah ditentukan terlebih dahulu dan telah disepakati bersama.

\subsection{Jenis dan Sumber data Penelitian}

\subsubsection{Jenis Data}

Adapun jenis data dalam penelitian ini yang penulis ambil, yaitu sebagai berikut:

1. Data Kualitatif, yaitu berupa data atau informasi yang tidak berbentuk angka. Penulis mengangkat data tersebut dari hasil wawancara dengan Dinas Pariwisata Kabupaten Balangan Propinsi Kalimantan Selatan, yakni berupa data tentang sejarah instansi, struktur organisasi, bidang operasional yang dilakukan atau proses kerja.

2. Data Kuantitatif yaitu data yang berbentuk angka, yang diangkat dari dokumen instansi dalam hal ini tentang data jumlah pegawai, data tabulasi dan data lain yang berhubungan dengan penelitian.

\subsubsection{Sumber Data}

Adapun uraian data sumber data tersebut, yaitu:
1. Data Primer merupakan data penelitian yang diperoleh secara langsung dari sumber asli secara khusus di kumpulkan oleh peneliti untuk menjawab pertanyaan yang diajukan melalui daftar pertanyaan.

2. Data Sekunder merupakan data penelitian yang diperoleh secara tidak langsung melalui media perantara seperti informasi dan publikasi atau laporan historis yang telah tersusun dalam dokumen/arsip.

\subsection{Populasi dan Sampel}

Populasi dan sampel dalam penelitian ini ditentukan sebanyak 40 respoden.

\subsection{Teknik Pengumpulan Data}

1. Studi kepustakaan, yaitu pengumpulan data melalui atau mempelajari berbagai literatur dan bahan bacaan yang berhubungan dengan permasalahan yang akan dibahas.

2. Observasi, yaitu pengumpulan data melalui pengamatan secara umum pada Dinas Pariwisata Kabupaten Balangan Propinsi Kalimantan Selatan sebagai dasar untuk mengindentifikasi permasalahan yang akan dibahas.

3. Wawancara, yaitu mengumpulkan data dengan mengadakan tanya jawab secara lisan dengan pihak pegawai Dinas Pariwisata Kabupaten Balangan Propinsi Kalimantan Selatan dan peggiat pariwisata pada waktu yang telah ditentukan.

4. Dokumentasi, yaitu teknik pengumpulan data melalui pencatatan dan pengumpulan data instansi yang berkaitan dengan permasalahan yang akan dibahas.

5. Kuisioner, yaitu pengumpulan data dengan cara membagikan daftar pertanyaan secara tertulis kepada pegawai Dinas Pariwisata Kabupaten Balangan Propinsi Kalimantan Selatan dan penggiat pariwisata untuk memperoleh data primer yang diperlukan dalam penyusunan tesis ini.

\subsection{Teknik Analisis Data}

Dalam penelitian ini teknik pengolahan data yang akan dilakukan menggunakan metode kuantitatif. Analisis data penelitian menggunakan analisis regresi berganda dengan perangkat lunak spss. Berdasarkan hal tersebut, alat uji yang digunakan adalah :

\subsubsection{Uji Instrumen}

\section{Validitas}

Adapun penentuan atau pengambilan keputusan untuk valid instrumen pertanyaan adalah jika rhitung positif dan rhitung > rtabel maka 
instrument tersebut valid dan jika rtabel negative dan rhitung < rtabel maka instrument tidak valid.

\section{Reliabilitas}

Suatu konstruk atau variabel dikatakan reliabel jika memberikan nilai Cronbanch Alpha > 0,60 ( Ghozali,2009:90 ).

\subsubsection{Uji Asumsi Klasik}

\section{Uji Multikolinearitas}

Jadi nilai tolerance yang rendah sama dengan nilai VIF tinggi (karena $\mathrm{VIF}=1 /$ tolerance) dan menunjukkan adanya koloniritas yang tinggi dan multikolineritas dapat diketahui dengan memeriksa nilai VIF (variance inflation factor) yang merupakan unsur diagonal invers matrik korelasi sederhana antara perubah bebas. Apabila beberapa nilai VIF lebih dari $10 \mathrm{mk}$ multikolienearitas adalah sebuah masalah (Solimun, 2004, 35).

\section{Uji Heteroskedastisitas}

Pemeriksaan terhadap gejala heteroskedastisitas menurut Pratisto $(2004,155)$ adalah dengan melihat pola diagram pencar. Nilai dari diagram pencar yag residu dapat dilihat dari selisih antara nilai Y prediksi dengan Y observasi. Jika diagram pencar yang membentuk pola-pola tertentu yang teratur maka regresi mengalami gangguan heteroskedastisitas.

3. Uji Normalitas (kenormalan)

Bilamana hasil plot menujukkan pola garis lurus mendekati $45^{\circ}$ berarti asumsi normalitas terpenuhi.

\subsubsection{Uji Hipotesis}

\section{Analisis Regresi Berganda}

Adapun rumus dari regresi linier berganda adalah sebagai berkut:

$$
\mathbf{Y}=\mathbf{a}+\boldsymbol{\beta} 1 . \mathrm{X} 1+\boldsymbol{\beta} 2 . \mathrm{X} 2+\varepsilon
$$

\section{Uji F (simultan)}

Perbandingan Fhitung dengan Ftabel, yaitu jika Fhitung < Ftabel berarti $\mathrm{H}_{\mathrm{A}}$ ditolak dan jika Fhitung $>$ Ftabel berarti $\mathrm{H}_{\mathrm{A}}$ diterima.

\section{Uji Parsial}

Perbandingan thitung dengan ttabel, yaitu jika thitung < ttabel berarti $\mathrm{H}_{\mathrm{A}}$ ditolak dan jika thitung $>$ ttabel berarti $\mathrm{H}_{\mathrm{A}}$ diterima.

\section{Uji Variabel Dominan}

Untuk mengkaji variabel yang dominan digunakan indikator koefisien beta standardized dari variabel-variabel dari model regresi.

\section{BAB V}

ANALISIS HASIL PENELITIAN DAN PEMBAHASAN

\subsection{Analisis Hasil Penelitian}

5.1.1. Analisis Uji Instrumen Penelitian

\section{Uji Validitas}

Adapun uji validitas atas instrument didalam penelitian ini sebagai berikut:

Tabel 5.9

Hasil Uji Validitas

Variabel Kemampuan Kerja $\left(\mathrm{X}_{1}\right)$

\begin{tabular}{|c|c|c|}
\hline VARIABLE & RHITUNG & RTABEL \\
\hline $\mathrm{X}_{1.1}$ & $0,761(* *)$ & 0,312 \\
$\mathrm{X}_{1.2}$ & $0,742(* *)$ & 0,312 \\
$\mathrm{X}_{1.3}$ & $0,705(* *)$ & 0,312 \\
$\mathrm{X}_{1.4}$ & $0,802(* *)$ & 0,312 \\
$\mathrm{X}_{1.5}$ & $0,757(* *)$ & 0,312 \\
$\mathrm{X}_{1.6}$ & $0,747(* *)$ & 0,312 \\
$\mathrm{X}_{1.7}$ & $0,540(* *)$ & 0,312 \\
\hline
\end{tabular}

Sumber : data diolah (lihat lampiran 3 dan 6) Disimpulkan bahwa semua instrumen pertanyaan tersebut valid, ini terbukti nilai rhitung positip dan rhitung > rtabel, maka semua instrumen dari pertanyaan yang diajukan terhadap variabel kemampuan kerja $\left(\mathrm{X}_{1}\right)$ tersebut valid.

\section{Tabel 5.10}

\section{Hasil Uji Validitas}

Variabel Profesionalisme Pegawai $\left(\mathrm{X}_{2}\right)$

\begin{tabular}{|c|c|c|}
\hline VARIABLE & RHITUNG & RTABEL \\
\hline $\mathrm{X}_{2.1}$ & $0,860(* *)$ & 0,312 \\
$\mathrm{X}_{2.2}$ & $0,758(* *)$ & 0,312 \\
$\mathrm{X}_{2.3}$ & $0,825(* *)$ & 0,312 \\
$\mathrm{X}_{2.4}$ & $0,717(* *)$ & 0,312 \\
\hline
\end{tabular}

Sumber :data diolah (lihat lampiran 3 dan 6) Disimpulkan bahwa semua instrumen pertanyaan tersebut valid, ini terbukti nilai rhitung positip dan rhitung > rtabel, maka semua instrumen dari pertanyaan yang diajukan terhadap variabel profesionalisme pegawai $\left(\mathrm{X}_{2}\right)$ tersebut valid.

Tabel 5.11

Hasil Uji Validitas

Variabel Kinerja (Y)

\begin{tabular}{|c|c|c|}
\hline VARIABLE & RHITUNG & RTABEL \\
\hline Y1.1 & $0,674(* *)$ & 0,312 \\
Y1.2 & $0,907(* *)$ & 0,312 \\
Y1.3 & $0,877(* *)$ & 0,312 \\
Y1.4 & $0,842(* *)$ & 0,312 \\
Y1.5 & $0,849(* *)$ & 0,312 \\
\hline
\end{tabular}

Sumber :data diolah (lihat lampiran 3 dan 6)

Disimpulkan bahwa semua instrumen pertanyaan tersebut valid, ini terbukti nilai rhitung positip dan 
rhitung > rtabel, maka semua instrumen dari pertanyaan variabel kinerja (Y) tersebut valid.

\section{Uji Reliabilitas}

Berikut ringkasan hasil uji reliabilitas instrumen dalam penelitian ini.

Tabel 5.12

Hasil Uji Reliabilitas

\begin{tabular}{|l|c|c|}
\hline \multicolumn{1}{|c|}{ VARIABEL } & $\begin{array}{c}\text { CRONBACH'S } \\
\text { ALPHA }\end{array}$ & $\begin{array}{c}\text { NILAI } \\
\text { BAKU }\end{array}$ \\
\hline Kemampuan kerja $\left(\mathrm{X}_{1}\right)$ & 0,777 & 0,60 \\
Profesionalisem pegawai $\left(\mathrm{X}_{2}\right)$ & 0,812 & 0,60 \\
Kinerja (Y) & 0,813 & 0,60 \\
\hline
\end{tabular}

Sumber: data primer diolah (lihat lampiran 4)

Berdasarkan data pada tabel tersebut, diketahui semua variabel secara uji reliabilitas datanya reliabel atau datanya valid, karena masing-masing variabel menyatakan nilai cronbach's alphanya lebih besar dari nilai standar atau nilai baku.

\subsubsection{Uji Asumsi Klasik}

\section{Uji Multikolinieritas}

Berikut dapat disajikan akan data hasil uji multikolinieritas, yaitu:

\section{Tabel 5.13}

Hasil Uji Multikolinieritas

\begin{tabular}{|c|c|c|}
\hline \multirow{2}{*}{ VARIABEL } & \multicolumn{2}{|c|}{$\begin{array}{l}\text { COLLINIERARITY } \\
\text { STATISTIC'S }\end{array}$} \\
\hline & TOLERANCE & VIF \\
\hline $\begin{array}{l}\text { Kemampuan } \\
\text { kerja }\left(\mathrm{X}_{1}\right)\end{array}$ & 0,990 & 1,108 \\
\hline $\begin{array}{l}\text { Profesionalisme } \\
\text { pegawai }\left(\mathrm{X}_{2}\right)\end{array}$ & 0,998 & 1,210 \\
\hline
\end{tabular}

Sumber: data primer diolah (lihat lampiran 5)

Berdasarkan hasil perhitungan collinierarity statistic's pada tabel 5.14 terlihat bahwa nilai tolerance lebih besar dari $10 \%$ dan nilai variance inflation factor (VIF) di atas menunjukkan tidak ada satu pun variabel bebas yang memiliki nilai VIF lebih dari 10. Jadi dapat disimpulkan bahwa hasil penelitian ini tidak ada gejala multikolinieritas antar variabel bebas dalam model regresi.

\section{Uji Heteroskedastisitas}

Berdasarkan grafik scatterplots terlihat titik-titik menyebar secara acak serta tersebar baik di atas maupun di bawah angka 0 pada sumbu Y. Hal ini dapat disimpulkan bahwa tidak terjadi heteroskedastisitas pada model regresi, sehingga model regresi layak dipakai untuk memprediksi variabel kinerja berdasarkan pengaruh variabel kemampuan kerja dan profesionalisme pegawai.

\section{Uji Normalitas}

Grafik histogram maupun grafik normal p-p plot yang menunjukkan bahwa grafik histogram memberikan pola distribusi yang mendekati normal, sedangkan pada grafik normal $p$ - $p$ plot terlihat titik-titik menyebar disekitar garis diagonal, serta penyebarannya mengikuti arah garis diagonal. Grafik ini menunjukkan bahwa model regresi layak dipakai untuk memprediksi kinerja berdasarkan masukan dari variabel kemampuan kerja dan profesionalisme pegawai, karena memenuhi uji asumsi normalitas.

\subsubsection{Analisis Regresi}

Uji hipotesis menggunakan uji regresi berganda melalui program spss. Untuk pengujian hipotesis secara parsial dapat dilihat melalui hasil uji regresi berganda berikut ini :

\section{Tabel 5.14}

\section{Hasil Uji Regresi Berganda Coefficients(a)}

\begin{tabular}{|c|c|c|c|c|c|}
\hline & \multicolumn{2}{|c|}{$\begin{array}{l}\text { Unstandardized } \\
\text { Coefficients }\end{array}$} & \multirow{2}{*}{$\begin{array}{c}\text { Standardized } \\
\text { Coefficients } \\
\text { Beta }\end{array}$} & \multirow[b]{2}{*}{$\mathrm{t}$} & \multirow[b]{2}{*}{ Sig. } \\
\hline & B & $\begin{array}{l}\text { Std. } \\
\text { Error }\end{array}$ & & & \\
\hline (Constant) & 17,520 & 3,875 & & 4,521 & ,000 \\
\hline $\begin{array}{l}\text { Kemampuan } \\
\text { Kerja (X1) }\end{array}$ & 719, &, 117 & 784, & 6,145 & ,001 \\
\hline $\begin{array}{l}\text { Profesionalisme } \\
\text { Pegawai (X2) }\end{array}$ & ,848 & , 110 & ,833 & 7,709 & ,000 \\
\hline
\end{tabular}

a Dependent Variable: Kinerja (Y)

Sumber: data primer diolah (lihat lampiran 5)

Sebelum dilakukan pengujian hipotesis selanjutnya di jelaskan pula secara matematis model fungsi linear berganda dapat dinyatakan sebagai berikut:

$Y=17,520+0,719 X_{1}+0,848 X_{2}+\varepsilon$

\subsubsection{Uji Hipotesis}

Berdasarkan dari data hasil rekapitulasi tersebut dapat diolah hipotesis dalam penelitian ini sebagai berikut:

\section{Hipotesis Pertama $\left(\mathrm{H}_{1}\right)$}

Kemampuan kerja dan profesionalisme pegawai berpengaruh signifikan secara simultan terhadap kinerja pegawai pada Dinas Pariwisata Kabupaten Balangan Propinsi Kalimantan Selatan

Kemudian untuk mengetahui akan Fhitung dapat diketahui melalui data pada tabel berikut ini:

Tabel 5.15

Model ANOVA(b)

\begin{tabular}{|l|r|r|r|r|}
\hline & \multicolumn{1}{|c|}{ Df } & \multicolumn{1}{c|}{$\begin{array}{c}\text { Mean } \\
\text { Square }\end{array}$} & \multicolumn{1}{c|}{ F } & \multicolumn{1}{c|}{ Sig. } \\
\hline Regression & 2 & 48,543 & 7,722 &, $000(\mathrm{a}$ \\
Residual & 38 & 6,286 & & \\
Total & 40 & & & \\
\hline
\end{tabular}


Sumber : Lampiran 5

Hasil pengujian hipotesis secara yang mana diketahui bahwa Fhitung lebih besar dari Ftabel (Fhitung $=7,722>$ Ftabel $=3,252$ ) dan tingkat signifikansi $\mathrm{p}=0,000<0,05$. Tingkat kepercayaan yang diambil dalam penelitian ini sebesar 95\% dengan tingkat kesalahan $(\alpha)$ sebesar 5\%. Dengan demikian dapat disimuplkan uji hipotesis secara simultan diketahui bahwa variabel bebas berpengaruh terhadap variabel terikat. Berdasarkan hasil uji secara simultan tersebut, maka uji hipotesis pertama yang menyatakan kemampuan kerja dan profesionalisme pegawai berpengaruh signifikan secara simultan terhadap kinerja pegawai pada Dinas Pariwisata Kabupaten Balangan Propinsi Kalimantan Selatan, terbukti.

Uji Selanjutnya adalah untuk mengetahui uji determinan dari besarnya hubungan yang signifikan terhadap variabel terikat dengan variabel bebas dalam penelitian ini dapat dilihat pada tabel berikut ini:

\section{Tabel 5.16}

\section{Hasil Uji Regresi Model Summary(b)}

\begin{tabular}{|c|c|c|c|c|}
\hline Model & $\mathrm{R}$ & R Square & $\begin{array}{c}\text { Adjusted } \\
\text { R } \\
\text { Square }\end{array}$ & $\begin{array}{l}\text { Std. Error } \\
\text { of the } \\
\text { Estimate }\end{array}$ \\
\hline 1 & ,803(a) &, 763 &, 623 & 14,483 \\
\hline
\end{tabular}

Sumber : Lampiran 5

Berdasarkan tabel tersebut terlihat nilai Multiple $\mathrm{R}$ yaitu sebesar 0,803 mendekati angka 1 sedangkan variabel bebas tersebut mampu menjelaskan perubahan kinerja pegawai selain itu untu melihat besarnya pengaruh variabel bebas dapat dilihat dari nilai R Square sebesar 76,3\% $(\mathrm{R} 2=0,763)$, berdasarkan data ini diketahui besar pengaruh secara simultan adalah sebesar $76,3 \%$. Hal ini menjelaskan adanya hubungan yang sangat kuat antara variabel bebas dengan variabel terikat sedangkan sisanya sebesar $100 \%$ - $76,3 \%=23,7 \%$ atau 0,237 dipengaruhi oleh variabel lain yang tidak termasuk dalam penelitian ini seperti variabel perilaku pegawai, manajemen organisasi, motivasi kerja dan lainlain.

\section{Hipotesis Kedua $\left(\mathrm{H}_{2}\right)$}

Kemampuan kerja dan profesionalisme pegawai berpengaruh signifikan secara parsial terhadap kinerja pegawai pada Dinas Pariwisata Kabupaten Balangan Propinsi Kalimantan Selatan

\begin{tabular}{|l|c|c|c|}
\hline \multicolumn{1}{|c|}{ Variabel } & Beta & Thitung & Sig \\
\hline Kemampuan Kerja (X1) & 0,784 & 6,145 &, 001 \\
\hline Profesionalisme Pegawai (X2) & 0,833 & 7,709 &, 000 \\
\hline
\end{tabular}

Sumber : Lampiran 5

Melihat dari data tersebut, maka dapat digambarkan hasil pengujian hipotesis kedua ini sebagai berikut :

1) Variabel kemampuan kerja (X1) terhadap kinerja pegawai (Y)

Uji parsial untuk variiabel kemampuan kerja terhadap kinerjapegawai, yaitu dengan membandingkan thitung dengan ttabel, maka didapat hasil seperti thitung $=6,145>$ ttabel $=$ 1,687 , tingkat signifikansi $\mathrm{p}=0,001<0,05$. Tingkat kepercayaan yang diambil dalam penelitian ini sebesar 95\% dengan tingkat kesalahan $(\alpha)$ sebesar 5\%. Ini berarti hipotesis kedua terkait dengan pengaruh antara variabel kemampuan kerja (X1) dengan variabel terikat yaitu kinerja pegawai (Y) disimpulkan mempunyai pengaruh signifikan. Besarnya pengaruh variabel kemampuan kerja (X1) terhadap kinerja pegawai (Y) dapat diketahui dari Standardized Coefficients Beta 0,784 yang berarti kemampuan kerja dapat mempengaruhi kinerja pegawai sebesar $78,4 \%$

2) Variabel profesionalisme pegawai (X2) terhadap kinerja pegawai (Y)

Uji parsial untuk variabel profesionalisme pegawai terhadap kinerja pegawai, yaitu dengan membandingkan thitung dengan ttabel, maka didapat hasil seperti thitung $=7,709>$ ttabel $=$ 1,687 , tingkat signifikansi $\mathrm{p}=0,000<0,05$. Tingkat kepercayaan yang diambil dalam penelitian ini sebesar $95 \%$ dengan tingkat kesalahan $(\alpha)$ sebesar 5\%. Ini berarti hipotesis kedua terkait dengan pengaruh antara variabel profesionalisme pegawai (X2) di dengan variabel terikat yaitu kinerja pegawai disimpulkan mempunyai pengaruh signifikan.Besarnya pengaruh variabel profesionalisme pegawai (X2) terhadap kinerja pegawai (Y) dapat diketahui dari Standardized Coefficients Beta 0,833 yang berarti profesionalisme pegawai dapat mempengaruhi kinerja pegawai sebesar $83,3 \%$.

Kesimpulannya pada pengujian hipotesis kedua yakni kemampuan kerja dan profesionalisme pegawai berpengaruh signifikan secara parsial terhadap kinerja pegawai pada Dinas Pariwisata Kabupaten Balangan Propinsi Kalimantan Selatan, terbukti.

\section{Hipotesi Ketiga (Uji Dominan)}

Profesionalisme pegawai berpengaruh dominan terhadap kinerja pegawai pada Dinas Pariwisata 
Kabupaten Balangan Propinsi Kalimantan

Selatan

Hasil pengujian hipotesis ke tiga menunjukkan bahwa variabel bebas yang mempengaruhi variabel terikat secara dominan adalah profesionalisme pegawai (X2) karena mempunyai nilai Standardized Coefficients Beta paling tinggi, yaitu sebesar 0,833 bila dibanding dengan variabel kemampuan kerja sebesar 0,784, maka dapat disimpulkan bahwa hipotesis ke tiga variabel yang dominan mempengaruhi kinerja pegawai adalah variabel profesionaliseme pegawai, maka hipotesis 3 terbukti.

\subsection{Pembahasan}

1. Kemampuan kerja dan profesionalisme pegawai berpengaruh signifikan secara simultan terhadap kinerja pegawai pada Dinas Pariwisata Kabupaten Balangan Propinsi Kalimantan Selatan.

Dalam penelitian ini kemampuan kerja dan profesionalisme pegawai berpengaruh signifikan secara simultan terhadap kinerja pegawai pada Dinas Pariwisata Kabupaten Balangan Propinsi Kalimantan Selatadn, penelitian ini sejalan dengan hasil penelitian yang Agus Mulyanto, 2010, yang mana dalam penelitiannya menyatakan bahwa kemampuan Kerja dan Profesionalisme Pegawai berpengaruh signifikan terhadap kinerja, bedasarkan hasil penelitian tersebut, maka Dinas Pariwisata Kabupaten Balangan Propinsi Kalimantan Selatan harus lebih meningkatkan kembali akan kemampuan kerja dan profesionalisme pegawai serta memberikan dan mengembangkan kemampuan penggiat pariwisata untuk lebih profesional lagi dalam mengelola obyek wisata. Usaha yang dapat dilakukan bagi pegawai dan penggiat wisata adalah dengan memberikan pelatihan tentang bagaimana pentingnya manajemen pengelolaan industri wisata, agar pegawai dan penggiat pariwisata mempunyai kemampuan dan profesionalisme dalam mengelola wisata.

2. Kemampuan kerja dan profesionalisme pegawai berpengaruh signifikan secara parsial terhadap kinerja pegawai pada Dinas Pariwisata Kabupaten Balangan Propinsi Kalimantan Selatan.

Pengujian hipotesis kedua juga terbukti bahwa kemampuan kerja dan profesionalisme pegawai berpengaruh signifikan secara parsial terhadap kinerja pegawai pada Dinas Pariwisata Kabupaten Balangan Propinsi Kalimantan Selatan, penelitian ini sejalan dengan hasil penelitian yang Agus Mulyanto, 2010, yang mana dalam penelitiannya menyatakan bahwa kemampuan Kerja dan Profesionalisme Pegawai berpengaruh signifikan secara parsial terhadap kinerja. Berdasarkan hal tersebut, maka hendakya pihak Dinas Pariwisata Kabupaten Balangan Propinsi Kalimantan Selatan, selalu berusaha meningkatkan kemampuan dan profesionalisme pegawainya.

3. Profesionalisme pegawai berpengaruh dominan terhadap kinerja pegawai pada Dinas Pariwisata Kabupaten Balangan Propinsi Kalimantan Selatan

Hasil penelitian pada hipotesis ketiga variabel profesionalisme pegawai berpengaruh dominan terhadap kinerja pegawai pada Dinas Pariwisata Kabupaten Balangan Propinsi Kalimantan Selatan, penelitian ini sejalan dengan hasil penelitian yang Agus Mulyanto, 2010, yang mana dalam penelitiannya bahwa Profesionalisme Pegawai berpengaruh signifikan dominan terhadap kinerja. Berdasarkan hasil penelitian tersebut, maka Dinas Pariwisata Kabupaten Balangan Propinsi Kalimantan Selatan harus lebih memfokuskan permasalahan tersebut untuk dikembangkan dengan selalu menyelenggarakan kegiatan penataran dan pelatihan terhadap para pegawai, memberikan kesempatan kepada para pegawai untuk melanjutkan pendidikan ke tingkat lebih tinggi, mengirim atau menyekolahkan para pegawai dan menyelenggarakan kegiatan seminar, loka karya atau workshop yang berkaitan dengan peningkatan kualitas tenaga kerja.

\section{BAB VI PENUTUP}

\subsection{Kesimpulan}

1. Analisis hipotesis menyatakan bahwa kemampuan kerja dan profesionalisme pegawai berpengaruh signifikan secara simultan terhadap kinerja pegawai pada Dinas Pariwisata Kabupaten Balangan Propinsi Kalimantan Selatan.

2. Analisis hipotesis menyatakan bahwa kemampuan kerja dan profesionalisme pegawai berpengaruh signifikan secara parsial terhadap kinerja pegawai pada Dinas Pariwisata Kabupaten Balangan Propinsi Kalimantan Selatan.

3. Analisis hipotesis menyatakan bahwa profesionalisme pegawai berpengaruh dominan terhadap kinerja pegawai pada Dinas Pariwisata Kabupaten Balangan Propinsi Kalimantan Selatan.

\subsection{Saran}


1. Dinas Pariwisata Kabupaten Balangan Propinsi Kalimantan Selatan perlu meningkatkan kembali kemampuan kerja pegawai dengan memberikan pelatihan secara kontinyu dan memberikan kesempatan kepada para pegawai untuk melanjutkan pendidikan ke tingkat lebih tinggi, mengirim atau menyekolahkan para pegawai, menyelenggarakan kegiatan seminar, lokal karya atau workshop yang berkaitan dengan peningkatan kualitas pegawai dan menyediakan fasilitas dan bantuan dana kepada para pekerja yang berprestasi untuk meningkatkan keahlian dibidangnya.

2. Guna meningkatkan profesionalisme pegawai pihak instansi perlu meningkatkan kembali akan profesionalisme pegawai dengan carameningkatkan komitmen kerja pegawai melalui pembinaan, selalu menamakankepada pegawai tanggungjawab dalam bekerja, selalu meningkatkan kompetensi pegawai dalam bekerja melalui diklat.

3. Sehubungan dalam penelitian ini yang berpengaruh dominan adalah faktor profesionalisme kerja, maka usaha yang dapat dilakukan guna meningkatkan kinerja pegawai selain emberiakn diklat pihak instansi perlu juga menciptakan keharmonisan kerja, memberikan perhatian terhadap aktivitas kerja pegawai dan memberikan peningkatan peluang karier bagi pegawai.

\section{DAFTAR PUSTAKA}

Ancok. Heriawan 2011, Birokrasi dan Pengembangan PNS, Balai Pustaka, Jakarta As'ad, 2012, Kepegawaian, Rineka Cipta, Jakarta Armstrong dan Baron, 2010, Job Characteristics and Individual Characteristics on Job Satisfaction and Burnout in Community Nurses. International Journal Nurs. Stud, Vol. 33, No. 4.

Agus Mulyanto, 2010, Pengaruh Kemampuan Kerja, Budaya Organisasi dan Profesionalisme Pegawai Pada Kantor Kecamatan Banjarmasin Barat, FE Unlam, Banjarmasin

Arikunto, 2006, Metode Penelitian, Rineka Cipta, Jakarta

Akhamdi, 2011, Pengaruh Budaya Organisasi, Pendidiikan dan Profesional Pegawai Terhadap Kinerja Pegawai Pada Dinas Koperasi Kota Banjarmasin, FE Unlam, Banjarmasin

Budiarti, 2011, Manajemen Karier, Bumi
Aksara, Jakarta

Basri, Bafadal, 2009, Manajemen Sumber Daya Manusia. Jilid II. Prenhallindo Jakarta:.

Dessler, 2010, Management Human Research, Balai Pustaka, Jakarta

Dwi Anggara, 2013, Pengaruh Profesionalisme, Budaya Kerja dan Loyalitas Kerja Terhadap Kinerja Karyawan Sekretariat Daerah Kabupaten Jember, Universitas Merdeka, Surabaya

Erwinda Fauziah, 2010, Pengaruh Kemampuan Pegawai, Budaya Kerja dan Profesionalisme Pegawai Pada Dinas Pendapatan Kota Banjarmasin, Unlam, Banjarmasin

Ghozali, 2009, Metode Penelitian, Bumi Aksara, Jakarta

Gibson, 2010,Manajemen Sumber Daya

Manusia, (alih bahasa Kholi Irawan)

Fakultas Ilmu Administrasi Universitas Brawijaya, Malang

Gomes Faustino.C., 2010, Manajemen Sumber

Daya Manusia, Andi, Yogyakarta

Guritno dan Waridin, 2011, Manajemen Ketenagakerjaan dan Bisnis, Rineka Cipta, Jakarta

Handoko. T. Hani, 2010, Manajemen Sumber Daya Manusia dan Kepersonalian, Jilid III, BPFE, Yogyakarta

Hamalik,2013, Profesionalisme Kerja, Rineka Cipta, Jakarta

Hasibuan, 2010. Organisasi Perilaku, Struktur, Bina Rupa Aksara, Jakarta

Kartasasmita, 2014, Menuju Pegawai Yang Profesional dan Berintegritas, Bumi Aksara, Jakarta

Kamus Bahasa Indonesia, 2009, Gramedia, Jakarta

Makmur Jaya Kurniawan, 2013,

Manajemen Pariwisata, Linerty,

Jakarta

Mangkunegara. Anwar Prabu. 2015.

Manajemen Sumber Daya Manusia.

PT Ramaja Rosdakarya. Bandung

Moekijat, 2010, Manajemen Sumber Daya Manusia, Balai Pustaka, Jakarta

Nitisemito, 2011, Manajemen SDM dan Keperrsonaliaan, Ghalia Indonesia, Jakarta

Notoatmodjo dan Soekidjo, 2011, Pengembangan Sumber Daya Manusia, Rineka Cipta, Jakarta

Pratisto, Arif, 2004, Cara Mudah Mengatasi Statistik dan Rancangan Percobaan 
dengan SPSS 12, PT Elex Media Komputindo Kelompok Gramedia, Jakarta

Rivai, Veithzal, 2012, Manajemen Sumber Daya Manusia Untuk Perusahaan, Edisi Kedua,

PT. RajaGrafindo Persada Jakarta

Ranupandojo dan Husnan, 2010, Manajemen

Sumber daya Manusia, BPFE, Yogyakarta

Robbins, 2011, Manajemen dan Perencanaan Sumber Daya Manusia, Preselindo, Jakarta

Sanyoto, 2010, Perilaku dan Ruang Lingkup Kepegawaian, Bumi Aksara, Jakarta

Suradinata, 2015, Perilaku Keroganisasian, Balai Pustaka, Jakarta

Solimun, Pelatihan Metodologi dan Komputer Statistik, Seminar Dua Hari Tanggal 2627 Nopember 2004 di Banjarmasin

Supranto, 2005, Metode Penelitian Ilmiah, Bumi Aksara, Jakarta

Saputro, 2010, Perilaku dan Budaya Kerorganisasian, Bumi Aksara, Jakarta

Suseno, 2011, Manajemen Keorganisasian dan Profesionalisme Pegawai, Bina Rupa Aksara, Jakarta

Sedarmayanti, 2011, Manajemen Sumber Daya Manusia, Edisi Kedua, Penerbit STIE YKPN, Jakarta

Siagian. F. Sondkah, 2011, Manajemen SDM dan Kepegawaian, BPFE, Yogyakarta

Simamora. Hendry, 2012, Manajemen Sumber Daya Manusia, Edisi Kedua, Penerbit STIE YKPN, Yakarta

Soeprihantono, 2012, Manajemen Perusahaan, PT. Rajawali Press, Jakarta

Swasto, 2010, MSDM dan Kepersonalian, Rineka Cipta, Jakarta

Sugiono, 2009, Metode Penelitian, Rineka Cipta, Jakarta

Tjokrowinoto, 2016, Proffesionalisme Aparatur Negara, Universitas Indonesia, Jakarta

Timpe, 2009, Management, (alih bahasa Rudiantoro) Univeristas Indonesia, Jakarta

Undang-undang Nomor 8 Tahun 1974 tentang Pokok-pokok Kepegawaian serta dalam kerangka implementasi

Undang-undang Nomor 10 Tahun 2009 tentang Kepariwisataan, Jakarta

Undang-undang Nomor 32 Tahun 2004 tentang Pemerintahan Daerah beserta peraturan pelaksanaan lainnya

Wignjosoebroto, 2010, Manajemen Pengelolaan
SDM, Pusaka Tjaya, Surabaya
Wenny Putri,
2011,
Pengaruh
Profesionalisme,Budaya Kerja dan
Tingkat Pendidikan Terhadap Kinerja Pegawai Pada Dinas Kesehatan Kota Banjarmasin, FE Unlam, Banjarmasin

Winardi, 2011, Manajemen, Nova, Bandung

Zohar dan Marshall, 2010, Organizational climate, job satisfaction and job anxiety. Psychological Studies, Vol.34, pp.21-27. 